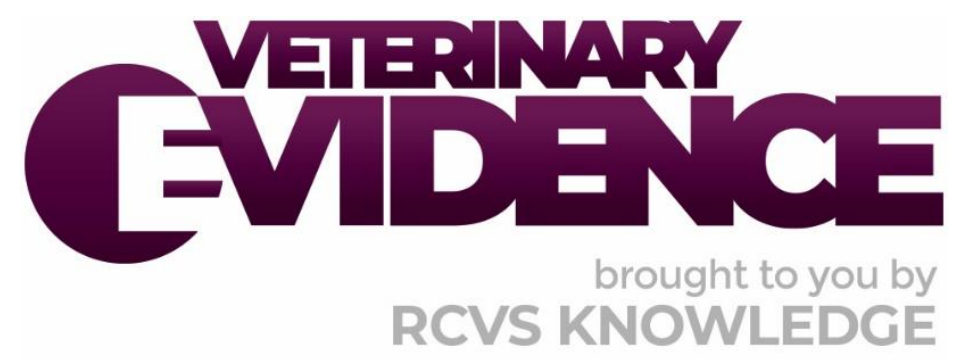

\title{
Is removal of proximo-plantar osteochondral fragments necessary in young Thoroughbreds?
}

\section{A Knowledge Summary by}

Julia Dubuc DMV, DÉS, DACVS-LA, M.SC, MRCVS ${ }^{1 *}$

Christopher Akkari BVMedSci (Hons), BVM BVS (Hons), MRCVS²

\footnotetext{
${ }^{1}$ University of Nottingham, Sutton Bonnington Campus, Sutton Bonnington, Leicestershire, LE12 5RD

2 Ringneill Equine Clinic, 53 Ringneill Road, Comber, Newtownards, BT23 6EF

*Corresponding Author (julia.dubuc@nottingham.ac.uk)
}

ISSN: 2396-9776

Published: 04 Oct 2019

in: Vol 4, Issue 4

DOI: 10.18849/VE.V4I4.186

Reviewed by: Peter Clegg (MA, VetMB, PhD, CertES, DipEVCS, MRCVS) and Christopher Bruce Riley (BSc, BVSc(Hons), MSc, PhD, Dipl ACVS, PGCInnovMgt, MANZCVS)

Next Review Date: 03 Jun 2020 


\section{KNOWLEDGE SUMMARY}

\section{PICO question}

In young Thoroughbreds with osteochondral fragments of the proximo-plantar aspect of the proximal phalanx, does pre-emptive surgical removal of the fragments compared to conservative (non-surgical) management reduce the incidence of subsequent lameness?

\section{Clinical bottom line}

There is currently insufficient data to determine the impact, on subsequent lameness, of conservative versus surgical management of proximo-plantar osteochondral fragments in young Thoroughbreds. Indeed, only three relevant studies were found, which include one retrospective study and two smaller case series. Since there are no substantive studies that have specifically focused on the treatment of plantar osteochondral fragmentation in Thoroughbred racehorses, the strength of evidence currently available is low.

\section{Clinical Scenario}

You are required to perform prepurchase radiographs (including both stifles, tarsi and carpi as well as all four fetlocks) on a young racing thoroughbred. All joints radiographed are unremarkable aside from the left metatarsophalangeal joint, which presents a proximo-plantar osteochondral fragment (PIOF) of the medial aspect of the proximal phalanx. While the horse's training is well under way, it has not raced yet. No lameness has been reported by the trainer and there is no obvious joint effusion on physical examination. However, the response to full hindlimb flexion is positive. The trainer asks if surgical removal is advised at this stage.

\section{Summary of the evidence}

\begin{tabular}{|c|c|}
\hline Barclay et al. (1987) & \\
\hline Population: & $\begin{array}{l}\text { - Horses } \\
\text { - Review of medical records of horses presented for lameness } \\
\text { caused by PIOF of the proximal phalanx } \\
\text { - Only two horses presented with a moderate hindlimb lameness } \\
\text { on physical examination } \\
\text { - The other } 17 \text { cases presented no lameness } \\
\text { - Regional or intra-articular anaesthesia of the } \\
\text { metatarsophalangeal joint did eliminate the existing lameness } \\
\text { (number unknown) } \\
\text { - None of the horses were positive to fetlock flexion, but all were } \\
\text { positive to hock flexion }\end{array}$ \\
\hline Sample size: & $\mathrm{N}=19$ horses \\
\hline Intervention details: & $\begin{array}{l}\text { All horses were divided into two groups: } \\
\text { - Surgical removal (arthrotomy) in } 10 \text { horses } \\
\text { - } \quad \text { Conservative treatment in nine horses }\end{array}$ \\
\hline
\end{tabular}




\begin{tabular}{|c|c|c|}
\hline & $\begin{array}{l}0 \\
0 \\
0\end{array}$ & $\begin{array}{l}\text { Intra-articular polysulphated glycosaminoglycans (PSGAGs) } \\
\text { in five horses (up to } 5 \text { times, weekly intervals, no specific } \\
\text { dosage given) } \\
\text { Intra-articular corticosteroids in two horses (up to } 2 \text { years, } \\
\text { every } 2 \text { months or so, no specific dosage given) } \\
\text { No treatment for two horses (classified as conservative } \\
\text { management by Barclay et al.) } \\
\text { Follow-up information was acquired by examination or } \\
\text { telephone conversation with the owner or the trainer }\end{array}$ \\
\hline Study design: & \multicolumn{2}{|c|}{ Retrospective case series } \\
\hline Outcome studied: & \multicolumn{2}{|c|}{$\begin{array}{l}\text { Return to previous level of training or performance or pre-lameness } \\
\text { level (unclear) }\end{array}$} \\
\hline $\begin{array}{l}\text { Main findings: } \\
\text { (relevant to PICO question): }\end{array}$ & \multicolumn{2}{|c|}{$\begin{array}{l}\text { - Of the } 10 \text { horses in the surgical group, all returned to training or } \\
\text { to performing at previous or above presurgical level } \\
\text { - Of the nine horses treated conservatively, } 8(89 \%) \text { were unable } \\
\text { to perform at pre-lameness levels: } \\
\text { The five horses treated with intra-articular PSGAGs had } \\
\text { some temporary relief of clinical signs } \\
\text { One horse received PSGAGs } 3 \text { times, at weekly interval, } \\
\text { swam instead of training and returned at higher racing level } \\
\text { The two horses treated with intra-articular corticosteroids } \\
\text { showed relief from lameness for } 2 \text { months } \\
\text { One of the two horses not treated was retired immediately } \\
\text { and the other one was sold as failing to train as required } \\
\text { speed }\end{array}$} \\
\hline Limitations: & \multicolumn{2}{|c|}{$\begin{array}{l}\text { - Small number of cases } \\
\text { - Outcome is unclear (what defines pre-lameness level is not } \\
\text { specified) and earnings could have been used to standardise } \\
\text { - Very little detail regarding the population (breed, sex, age, etc.) } \\
\text { and their intended purpose, including if raced prior to entering } \\
\text { the study } \\
\text { - Unknown number of metatarsophalangeal joint blocked for } \\
\text { diagnosis } \\
\text { - No information on fragment location within the joint or the type } \\
\text { of fragmentation (I: articular vs II: nonarticular) nor concurrent } \\
\text { intra-articular lesion found in surgery } \\
\text { - No details regarding the type and amount of corticosteroid nor } \\
\text { amount of PSGAGs used } \\
\text { - No detailed information regarding follow-up (including length of } \\
\text { follow-up, if further joint medication was required, if any } \\
\text { lameness recurred, etc.) } \\
\text { No control (fragment free) group }\end{array}$} \\
\hline
\end{tabular}




\begin{tabular}{|c|c|}
\hline Whitton et al. (1994) & \\
\hline Population: & 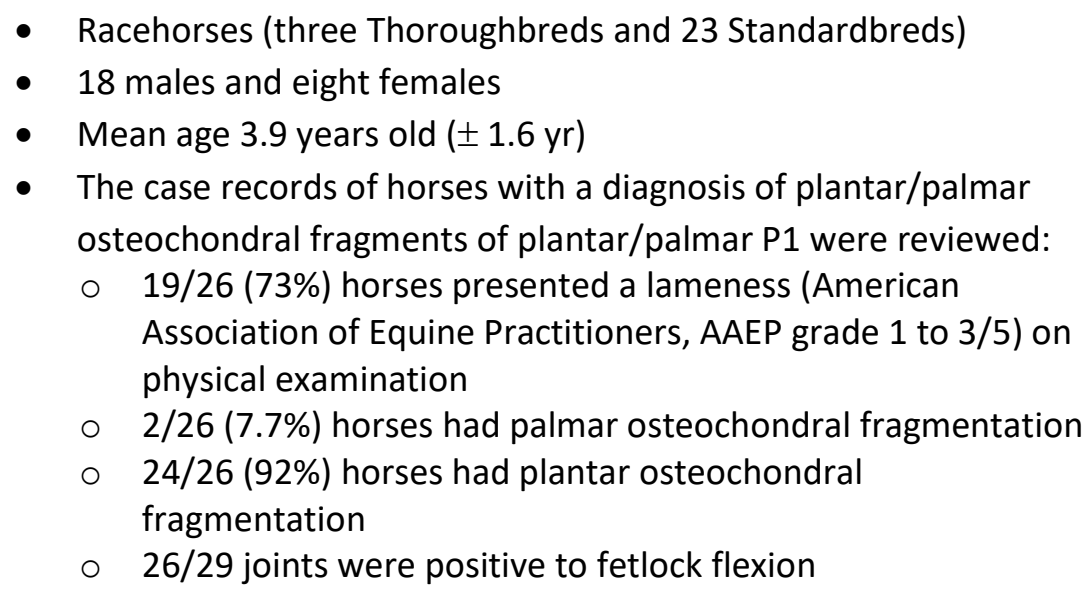 \\
\hline Sample size: & 26 horses ( 29 joints) \\
\hline Intervention details: & $\begin{array}{l}\text { Horses were divided into two groups: } \\
\text { - Surgical removal (arthroscopy ( } 23 \text { joints in } 21 \text { horses and } 1 \\
\text { arthrotomy in one horse) } \\
\text { - Conservative treatment (non-defined by authors) in four horses: } \\
\text { O One had intra-articular injection of } 120 \mathrm{mg} \\
\text { methylprednisolone acetate (MPA) } \\
\text { - Follow-up information was acquired by examination or } \\
\text { telephone conversation with the owner or the trainer }\end{array}$ \\
\hline Study design: & Retrospective case series \\
\hline Outcome studied: & Return to previous performance level or to racing (unclear) \\
\hline $\begin{array}{l}\text { Main findings: } \\
\text { (relevant to PICO question): }\end{array}$ & 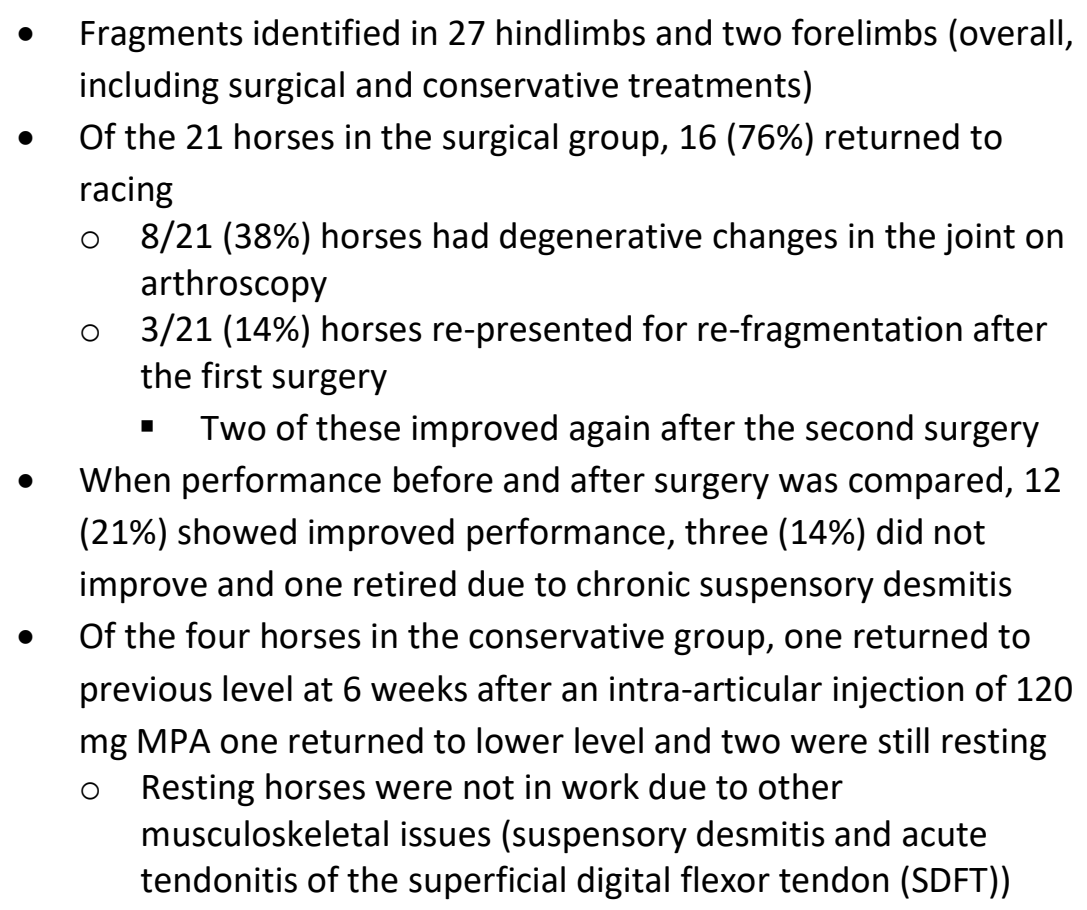 \\
\hline Limitations: & $\begin{array}{l}\text { - Only three Thoroughbreds included } \\
\text { - Outcome is unclear and earnings could have been used to } \\
\text { standardise }\end{array}$ \\
\hline
\end{tabular}




\begin{tabular}{|l|l|}
\hline - $\begin{array}{l}\text { Unknown number of metatarsophalangeal joint blocked for } \\
\text { diagnosis }\end{array}$ \\
- $\begin{array}{l}\text { No information on fragment location within the joint or the type } \\
\text { of fragmentation (I vs II) } \\
\text { - }\end{array}$ \\
$\begin{array}{l}\text { No detailed information regarding follow-up (including length of } \\
\text { follow-up, if further joint medication was required, if any } \\
\text { lameness recurred, etc.) }\end{array}$ \\
- $\begin{array}{l}\text { No control (fragment free) group } \\
\text { Some horses appear unaccounted for in the result section and it } \\
\text { is unclear how many were lost to follow-up }\end{array}$ \\
\hline
\end{tabular}

\begin{tabular}{|c|c|}
\hline \multicolumn{2}{|l|}{ Fortier (1995) } \\
\hline Population: & $\begin{array}{l}\text { - Thoroughbreds (three), Standardbred racehorses (109), Quarter } \\
\text { Horses (two), Warmbloods (two), Arabian (one), American } \\
\text { Saddle Horse (one) } \\
\text { - } 47 \text { females, } 27 \text { colts, } 45 \text { geldings } \\
\text { - } \text { Majority }(93 \%)<3 \text { years old } \\
\text { - } \text { Medical records of horses that had a diagnosis of palmar/plantar } \\
\text { osteochondral fragments arthroscopically removed were } \\
\text { included } \\
\text { - } 82 \text { horses had a lameness examination performed: } \\
\circ \quad \text { Lameness reported to be mild by clinician } \\
\circ \quad 17 / 82 \text { horses (21\%) had slight to moderate positive hock } \\
\quad \text { flexion }\end{array}$ \\
\hline Sample size: & $\mathrm{N}=119$ horses \\
\hline Intervention details: & $\begin{array}{l}\text { - All fragments included were type I (axial) } \\
\text { - All horses included had surgical removal of the fragments in } \\
\text { arthroscopy } \\
\text { - Follow-up information was acquired by examination or } \\
\text { telephone conversation with the owner or the trainer and } \\
\text { confirmed via race records }\end{array}$ \\
\hline Study design: & Retrospective study \\
\hline Outcome studied: & $\begin{array}{l}\text { - For racehorses, successful if mean postoperative earnings/race } \\
\text { were equal or above the pre-operative earnings/race } \\
\text { - For the non-racehorses, successful if return to pre-operative } \\
\text { performance level }\end{array}$ \\
\hline $\begin{array}{r}\text { Main findings: } \\
\text { (relevant to PICO question): }\end{array}$ & $\begin{array}{l}\text { - Full-thickness cartilage defects identified by arthroscopy in 9/155 } \\
\text { (6\%) metatarsophalangeal joints and in none of the forelimbs } \\
\text { - } 22 / 109 \text { (20\%) Standardbred did not have a career start at the } \\
\text { time of follow-up: } \\
\circ 6 / 22(27 \%) \text { were in training and sound } \\
\text { - } 87 / 109(80 \%) \text { Standardbred racehorses that previously raced } \\
\text { returned to racing: } \\
\circ 55 / 87(63 \%) \text { were back at or above preoperative level }\end{array}$ \\
\hline
\end{tabular}




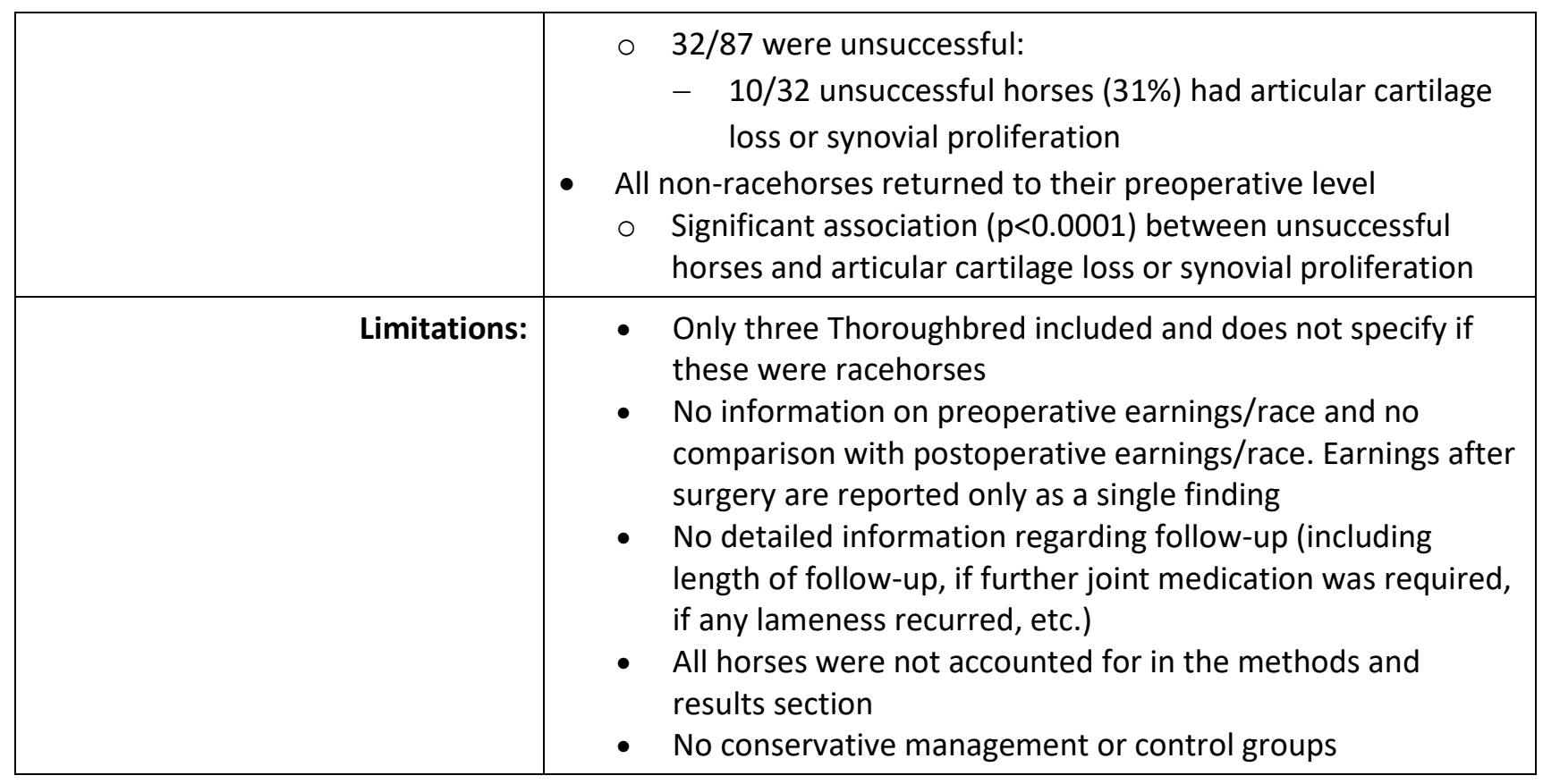

\section{Appraisal, application and reflection}

There are very few studies evaluating the impact of proximo-plantar osteochondral fragmentation (PIOF) in young thoroughbreds. By contrast, a larger number of publications on PIOF of the proximal phalanx (P1) focused on standardbred racehorses and warmbloods is available. Based on the three studies mentioned above and taking into consideration that the breed of the horses included in the paper from Barclay et al. (1987) is not specified, a grand total of six Thoroughbreds were included and it remains unclear if all six were destined for racing.

The reported prevalence of PIOF of P1 in racing Thoroughbreds is $5.9 \%$, with $4.1 \%$ type I and $1.8 \%$ type II fragments (Kane et al., 2003). Both dorsal and plantar fragmentation were found to be twice as common in the hind fetlocks compared to forelimbs. The same authors (Kane et al., 2003), in their retrospective radiographic survey of yearling Thoroughbred sales, also reported twice as many type I fragmentation compared to type II and that these tended to be unilateral.

It is thought that PIOF of P1 would cause lameness at high speed, or mostly during performance (Fortier et al., 1995; Houttu, 1991; Whitton et al., 1994). As previously stated, this has been investigated mostly in another type of racehorse, the standardbred trotters. Carmalt et al. (2015) reported that standardbred racehorses which had osteochondral fragmentation of the proximo-palmar/plantar aspect of the proximal phalanx did not slow down prior to surgery, or speed up after. In a case-control study from the same group (Carmalt et al., 2014), 174 standardbred racehorses with PIOF were compared with ones radiographically normal (613 horses). No difference in race speed was found between the two groups before surgical removal. Moreover, the horses did not slow down prior to, nor sped up after surgery. The authors concluded that surgical removal of proximal palmar or plantar fragmentation was not recommended. Houttu (1991), in an older study including mainly standardbred trotters undergoing fragment removal, reported that $23 / 45(51 \%)$ of the horses successfully returned to training speed in 3 months and this increased to $41 / 45$ (91\%) at 6 months postsurgery. While this information is very valuable and relates to racehorses working at high speed, extrapolation of these findings to young Thoroughbreds is questionable.

Despite the evidence stated above appearing quite dated, these are the only three studies containing a variable number of Thoroughbreds to provide any follow-up information. There is no mention of a mean time to follow- 
up making it difficult to draw any conclusions regarding the soundness of these horses in the long-term. Although Whitton et al. (1994) reported three horses presenting refragmentation in previously operated joints, there is generally very few details regarding recurrence of the lameness and how this was subsequently addressed. Houttu (1991) reported that $3 / 45(6 \%)$ of the horses which underwent surgical removal of the fragmentation were lame 3 months after surgery when the trainer attempted working at high speed and that $2 / 45(4 \%)$ stayed lame due to a lesion located in the joint. However, these lesions are not described in the publication. Fortier et al. (1995) found significant association between unsuccessful racehorses and the presence of cartilage loss or synovial proliferation. While related articular cartilage or any other intra-articular pathology could influence potential future lamenesses, the data currently available in the literature is presented in ways not amenable to comparison between the different studies: 9/155 metatarsophalangeal joints had full thickness articular cartilage defect (Fortier et al., 1995) whereas $8 / 21$ horses (38\%) had intraarticular degenerative changes in arthroscopy (Whitton et al., 1994). A clear, exhaustive description of concurrent intra-articular pathology and long-term follow-up of these specific cases is needed to determine the impact of surgical or conservative management of PIOF of P1 on subsequent lameness.

The authors failed to find studies including a separate group composed of fragment free Thoroughbred horses, to act as control group as well as a conservative and surgical group. While the papers from Barclay et al. (1987) and Whitton et al. (1994) compare surgical and conservative management of these fragments, higher quality evidence, in the form of a prospective study with an extensive long-term follow-up and more detailed description of intra-articular findings, is required to determine if pre-emptive surgical removal of PIOF of the proximal phalanx is warranted and reduces the risk of lameness.

As previously mentioned, supplemental literature concerning proximal phalanx osteochondral fragmentation is available namely in warmbloods (Declercq et al., 2011; Declercq et al., 2009; Declercq et al., 2008) and also concerning dorsal osteochondral fragmentation of the proximal phalanx in Thoroughbreds (Walsh et al., 2018).

\section{Methodology Section}

\begin{tabular}{|c|c|}
\hline $\begin{array}{r}\text { Databases searched and dates } \\
\text { covered: }\end{array}$ & $\begin{array}{l}\text { CAB Abstracts } 1973 \text { to Week } 182018 \\
\text { PubMed NCBI } 1900 \text { to Week } 232018\end{array}$ \\
\hline Search terms: & $\begin{array}{l}\text { CAB Abstracts } \\
\text { 1. (equine* or horse* or equus or equid* or mare or mares or } \\
\text { broodmare* or 'brood mare*' or pony or ponies or filly or } \\
\text { fillies or colt or colts or stallion* or thoroughbred* or } \\
\text { standardbred* or racehorse* or 'race horse*').mp. or exp } \\
\text { horses/ or exp equus/ or exp equidae/ or exp mares/ or exp } \\
\text { colts/ or exp foals/ or exp stallions/ or exp thoroughbred/ or } \\
\text { exp racehorses/ } \\
\text { 2. ((osteochond* and (fragment* or chip or chips or dissecans)) } \\
\text { or OCF or OCD).mp. } \\
\text { 3. (((proximal or proximo) and plantar) or (proximal and } \\
\text { phalanx) or P1 or proximoplantar*).mp. } \\
\text { 4. (arthroscop* or surger* or surgical* or operat* or excision* } \\
\text { or excise* or dissect*).mp. or exp surgery/ or exp surgical } \\
\text { operations/ } \\
\text { 5. } 1 \text { and } 2 \text { and } 3 \text { and } 4\end{array}$ \\
\hline
\end{tabular}




\begin{tabular}{|c|c|}
\hline & $\begin{array}{l}\text { PubMed } \\
\text { 1. (equine* or horse* or equus or equid* or mare or mares or } \\
\text { broodmare* or 'brood mare*' or pony or ponies or filly or } \\
\text { fillies or colt or colts or stallion* or thoroughbred* or } \\
\text { standardbred* or racehorse* or 'race horse*') } \\
\text { 2. ((osteochond* and (fragment* or chip or chips or } \\
\text { dissecans)) or OCF or OCD) } \\
\text { 3. (((proximal or proximo) and plantar) or (proximal and } \\
\text { phalanx) or P1 or proximoplantar*) } \\
\text { 4. (arthroscop* or surger* or surgical* or operat* or excision* } \\
\text { or excise* or dissect*) } \\
\text { 5. } 1 \text { and } 2 \text { and } 3 \text { and } 4\end{array}$ \\
\hline Dates searches performed: & $14 / 5 / 2018$ and $3 / 6 / 2018$ \\
\hline
\end{tabular}

\section{Exclusion / Inclusion Criteria}

\begin{tabular}{|c|c|}
\hline Exclusion: & $\begin{array}{l}\text { - Articles not relevant to PICO question } \\
\text { O dorsoproximal fragments } \\
0 \text { other joints than fetlock } \\
0 \text { other breeds than thoroughbred only } \\
\text { - Conference papers/proceedings not published } \\
\text { Non-English language publications }\end{array}$ \\
\hline Inclusion: & $\begin{array}{l}\text { - Relevant to PICO question } \\
\circ \text { thoroughbred or thoroughbred racehorse } \\
\circ \text { conservative and surgical treatment, proximo-plantar } \\
\text { fragments of P1 }\end{array}$ \\
\hline
\end{tabular}

\begin{tabular}{|c|c|c|c|c|c|c|}
\hline \multicolumn{7}{|c|}{ Search Outcome } \\
\hline Database & $\begin{array}{c}\text { Number } \\
\text { of } \\
\text { results }\end{array}$ & $\begin{array}{l}\text { Excluded - } \\
\text { not } \\
\text { relevant to } \\
\text { PICO }\end{array}$ & $\begin{array}{l}\text { Excluded - } \\
\text { duplicates }\end{array}$ & $\begin{array}{l}\text { Excluded - } \\
\text { conference } \\
\text { papers not } \\
\text { published }\end{array}$ & $\begin{array}{l}\text { Excluded - } \\
\text { other } \\
\text { languages }\end{array}$ & $\begin{array}{c}\text { Total } \\
\text { relevant } \\
\text { papers }\end{array}$ \\
\hline $\begin{array}{l}\text { CAB } \\
\text { Abstracts }\end{array}$ & 25 & 18 & 0 & 1 & 3 & 3 \\
\hline PubMed & 45 & 38 & 7 & 0 & 0 & 0 \\
\hline \multicolumn{6}{|c|}{ Total relevant papers when duplicates removed } & 3 \\
\hline
\end{tabular}


The authors declare no conflicts of interest.

\section{REFERENCES}

1. Barclay, W., Foerner, J. and Phillips, T. 1987. Lameness attributable to osteochondral fragmentation of the plantar aspect of the proximal phalanx in horses: 19 cases (1981-1985). Journal of the American Veterinary Medical Association 191, 855-857.

2. Carmalt, J.L., Borg, H., Näslund, H. and Waldner, C. 2014. Racing performance of Swedish Standardbred trotting horses with proximal palmar/plantar first phalangeal (Birkeland) fragments compared to fragment free controls. The Veterinary Journal 202, 43-47.

DOI: https://doi.org/10.1016/j.tvjl.2014.07.017

3. Carmalt, J., Borg, H., Näslund, H. and Waldner, C. 2015. Racing performance in Standardbred trotting horses with proximal palmar/plantar first phalangeal fragments relative to the timing of surgery. Equine Veterinary Journal 47, 433-437. DOI: https://doi.org/10.1111/evj.12317

4. Declercq, J., Martens, A., Bogaert, L.., Boussauw, B., Forsyth, R. and Boening, K.J. 2008. Osteochondral fragmentation in the synovial pad of the fetlock in warmblood horses. Veterinary Surgery 37, 613-618. DOI: https://doi.org/10.1111/i.1532-950x.2008.00426.x

5. Declercq, J., Martens, A., Maes, D., Boussauw, B., Forsyth, R. and Boening, K.J., 2009. Dorsoproximal proximal phalanx osteochondralfragmentation_in 117 Warmblood horses. Veterinary and Comparative Orthopaedics and Traumatology 22, 1-6. DOI: https://doi.org/10.3415/vcot-08-02-0016

6. Declercq, J., Hauspie, S., Saunders, J. and Martens, A. 2011. Osteochondral fragments in the metacarpo- and metatarsophalangeal joint and their clinical importance. (Osteochondrale fragmenten in het kogelgewricht en hun klinisch belang) Vlaams Diergeneeskundig Tijdschrift, 80, 271-280.

7. Fortier, L., Foerner, J. and Nixon, A. 1995. Arthroscopic removal of axial osteochondral fragments of the plantar/palmar proximal aspect of the proximal phalanx in horses: 119 cases (1988-1992). Journal of the American Veterinary Medical Association 206, 71-74. DOI: https://doi.org/10.1111/j.1532950X.2004.04061.x

8. Houttu, J. 1991. Arthroscopic removal of osteochondral fragments of the palmar/plantar aspect of the metacarpo/metatarsophalangeal joints. Equine Veterinary Journal 23, 163-165.

DOI: https://doi.org/10.1111/j.2042-3306.1991.tb02747.x

9. Kane, A.J., Park, R.D., Mcllwraith, C.W., Rantanen, L.W., Morehead, J.P. and Bramlage, L. R. 2003. Radiographic changes in Thoroughbreds yearlings. Part I: Prevalence at the time of yearling sales. Equine Veterinary Journal 35, 354-365. DOI: https://doi.org/10.2746/042516403776014280

10. Walsh, R., Smith, M.R.W. and Wright, I.M. 2018. Frequency distribution of osteochondral fragmentation of the dorsoproximal articular surface of the proximal phalanx in racing thoroughbreds in the UK. Equine Veterinary Journal 50, 624-628. DOI: https://doi.org/10.1111/evj.12795 
11. Whitton, R. and Kannegieter, N. 1994. Osteochondral fragmentation of the plantar/palmar proximal aspect of the proximal phalanx in racing horses. Australian Veterinary Journal 71, 318-321.

DOI: https://doi.org/10.1111/i.1751-0813.1994.tb00906.x

\section{Acknowledgement}

RCVS Knowledge was supported in producing this Knowledge Summary by an educational grant from Petplan Charitable Trust. 


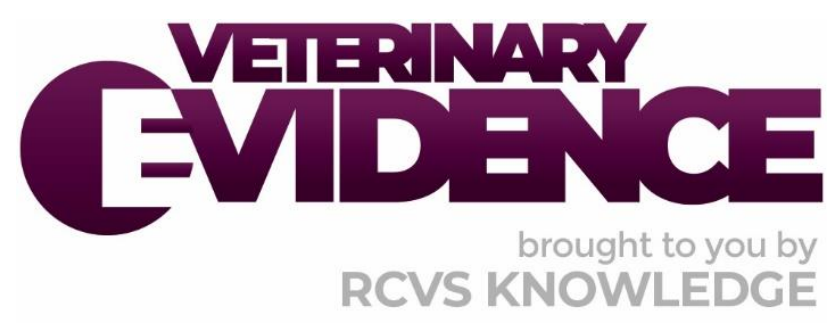

\section{Intellectual Property Rights}

Authors of Knowledge Summaries submitted to RCVS Knowledge for publication will retain copyright in their work, and will be required to grant RCVS Knowledge a non-exclusive license of the rights of copyright in the materials including but not limited to the right to publish, re-

publish, transmit, sell, distribute and otherwise use the materials in all languages and all media throughout the world, and to license or permit others to do so.

\section{Disclaimer}

Knowledge Summaries are a peer-reviewed article type which aims to answer a clinical question based on the best available current evidence. It does not override the responsibility

of the practitioner. Informed decisions should be made by considering such factors as individual clinical expertise and judgement along with patient's circumstances and owners' values. Knowledge Summaries are a resource to help inform and any opinions expressed within the Knowledge Summaries are the author's own and do not necessarily reflect the view of the RCVS Knowledge. Authors are responsible for the accuracy of the content. While the

Editor and Publisher believe that all content herein are in accord with current recommendations and practice at the time of publication, they accept no legal responsibility

for any errors or omissions, and make no warranty, express or implied, with respect to material contained within.

For further information please refer to our Terms of Use.

RCVS Knowledge is the independent charity associated with the Royal College of Veterinary Surgeons (RCVS). Our ambition is to become a global intermediary for evidence based veterinary knowledge by providing access to information that is of immediate value to practicing veterinary professionals and directly contributes to evidence based clinical decision-making.

https://www.veterinaryevidence.org/

RCVS Knowledge is a registered Charity No. 230886.

Registered as a Company limited by guarantee in England and Wales No. 598443.

Registered Office: Belgravia House, 62-64 Horseferry Road, London SW1P 2AF

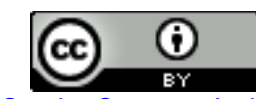

This work is licensed under a Creative Commons Attribution 4.0 International License 